\title{
BIBECHANA
}

A Multidisciplinary Journal of Science, Technology and Mathematics ISSN 2091-0762 (Print), 2382-5340 (Online)

Journal homepage: http://nepjol.info/index.php/BIBECHANA

Publisher: Research Council of Science and Technology, Biratnagar, Nepal

\section{Sources and causes of water pollution in Bangladesh: A technical overview}

\author{
Md. Arman Arefin, Avijjit Mallik* \\ Department of Mechanical Engineering, Rajshahi University of Engineering and Technology, \\ Rajshahi-6204, Bangladesh \\ "Email: avijitme13@gmail.com
}

Article history: Received 01 December, 2017; Accepted 09 December, 2017

DOI: http://dx.doi.org/10.3126/bibechana.v15i0.18688

This work is licensed under the Creative Commons CC BY-NC License.

https://creativecommons.org/licenses/by-nc/4.0/

\section{(c) (1) (8)}

Abstract

Water pollution is one of the significant dangers to general wellbeing of Bangladesh. Drinking water quality is inadequately overseen and checked. Bangladesh positions at number 86 among 142 countries with respect to drinking water quality. Drinking water sources, both surface and groundwater are debased with coliforms, harmful metals and pesticides all through the nation. Different drinking water quality parameters set by WHO are every now and again damaged. Human wastes, transfer of civil and mechanical wastes and aimless use of agrochemicals in agribusiness are the principle factors affecting the water quality. Microbial and substance contaminations are the primary elements work solely or in mix for different general medical issues. This paper presents a detailed layout of water quality in Bangladesh with unique inflection on significant poisons, sources and causes of pollution. The information introduced in this paper are extracted from different surveys and reports distributed in national and global journals; likewise reports discharged by the government and NGO associations are incorporated.

Keywords: Water Pollution; Causes of pollution; Sources of pollution; Bangladesh.

\section{Introduction}

Water they say is life, and to be sure they are correct. With around $70 \%$ of the world is covered by water, it certainly winds up plainly one of our most noteworthy assets. Water is used practically in every vital human tasks and procedures. It is a vital component in both household and additionally mechanical and industrial purposes. However a nearer investigation of our water assets today, gives us an impolite result.

Invaded with waste running from drifting plastic packs to synthetic waste, our water bodies have transformed into a pool of toxin. The defilement of water bodies in least complex word implies water pollution. Consequently the mishandle of lakes, seas, Rivers, repositories and so on are water 
pollution. Pollution of water occurs when substances that will adjust the water in negative mold are released in it. This release of poisons can be immediate and additionally backhanded [1]. Poison inputs have expanded in late decades and have corrupted water nature of numerous waterways, lakes, and seaside seas. Humiliation of these crucial water assets can be measured as the loss of normal frameworks, their segment species, and the comforts that they give [2-4]. Water deficiencies are progressively normal and liable to end up plainly more extreme later on [5-6]. Water lack and poor water quality are connected, in light of the fact that pollution lessens the supply of water and builds the expenses of treating water for utilization. Prevention pollution is among the most financially savvy methods for expanding water supplies. Just a little rate $(0.01 \%)$ of this crisp water is accessible for human use [7].

Water pollution is surpassing the breaking point in the greater part of the water sources, and has turned into a tremendous risk to the survival of water species. In the year 2011 in 'The Daily Star', Most of the news (added $38^{+}$news) were related to water pollution and were distributed in the months January and June. Detectable number of news likewise distributed in the month May and July.

\section{Previous work}

Fariha Binte Amin [8] published an article about the water pollution caused by oil and marine pollution. The article mainly focused on this causes of water pollution. G. Kibria et al [9] published a research article about the Buriganga river water pollution causes and consequences. The author mainly focused on the river water pollution due to waste disposal and industrial pollution. K. N. Mukti [10] worked on the water pollution effects on human life. Authors made a case study report on Bansi River, Savar, Dhaka. Muhammad Rezaul Kabir [11] discussed about the social impact of water pollution. Author mainly focused on how water pollution affects our social and economic life. G. J. Alam [12] discussed about the environmental pollution of Bangladesh and its effects. Author focused on several reasons of environmental pollution in Bangladesh. M. A. Bhuiyan [13] investigated the possible sources of heavy metal contamination in central and lagoon water in the tannery industrial area of Dhaka. M. Ahmad et al [14] investigated water pollution due to heavy metals and sediment in Buriganga River. Nasema Tanvir Chowdhury [15] investigated about the water management of Bangladesh. The paper identified various geographic, socioeconomic factors that shape the water management. M. A. Bhuiyan et al. [16] evaluated the hazardous metal pollution in irrigation and drinking water system near the coal mind area. The paper mainly focused on the coal mine water pollution.

From the literature it is seen that all the previous work were based on one or two causes of water pollution. No literature found which discussed the sources of water pollution in Bangladesh. This paper focused on the causes and sources of water pollution in a broad sense. Moreover, water pollution due to boating, wetland, and Road construction are not found in literature. The discussions based on these topics are also conducted in this paper.

\section{Methodology}

A detailed evaluation of different sectors of water pollution is present in this paper. First, the sources of water pollution are divided into two sectors (Point and Non-point).Point sources are not major reasons of water pollution in Bangladesh. Non-Point sources are described in details including urban land use and heavy rainfall, agricultural land and forestry land use, abandoned mines, hydro modification and habitant alteration, marines and boating, roads, highways and wetland areas. A detailed study about all these mentioned sectors are conducted is this paper. Then an elaborated study on the causes of water pollution in Bangladesh is present considering sewage and solid waste, industrial waste and effluents, inadequate sanitary facilities, arsenic contamination, oil pollution and global warming. All the data presented in this paper are collected from different government and nongovernment surveys, reports and reliable sources.

\section{Sources of Water Pollution}

Water pollution occurs regularly because of human exercises [17]. The significant ones are unpredictable transfer of mechanical, civil and household wastes in water channels, waterways, rivers and lakes, and so on [18]. An assessed 2 million tons of sewage and different effluents are released 
into the worlds waters each day. In creating nations the circumstance is more regrettable where more than $90 \%$ of crude sewage and $70 \%$ of untreated mechanical wastages are dumped into surface water sources [19]. The two main wellsprings of water pollution can be viewed as Point and Non-Point sources. Point sources are moderately simple to recognize, measure and control. Point sources of water pollution incorporate release from metropolitan sewage treatment plant and modern plant [20]. While Non-Point implies poisons radiated from different sources .the pollution can't be followed to a solitary purpose of release, hard to screen and control [2]. Non-point source pollution is water pollution that influences a water body from diffuse sources, for example, human land utilize and dirty spillover from rural regions depleting into a river [21, 22] Contaminated water after downpours that has gone through a few locales may likewise be considered as a Non-Point wellspring of pollution. Utilization of concentrated mineral composts related with tainting of rural groundwater prompts expanding level of supplements in ground and surface waters, particularly from non-point sources and hard to anticipate contrasted with point sources. Horticultural movement is major non-point sources pollution including utilization of nitrogen composts, use of domesticated animals excrement, vegetable obsession and mineralization of soil nitrogen [17].

\subsection{Point Sources}

"Point source water pollution is characterized as emanations which enter water from a sample single source, for example, a pipe from a production line or the outfall from a sewage works" [23]. This kind of pollution affects the condition of water. The released waste from firms can influence water groups of any size. Poisons can change the synthetic cosmetics of the water. They can influence oxygen levels, sharpness levels, green growth and micro-organisms development and even change water temperature. These things extraordinarily influence the sea life existence of these water bodies. Pollution of this kind turns into a hazard and along these lines a market disappointment when there is a negative effect on people notwithstanding the earth. With fish and shellfish being an essential nourishment source, gaming and recreational exercises happening on water bodies and with tap water giving a water source to savoring, pollution of the water can without much of a stretch convert into enormous issues for individuals - a genuine outer cost. Figure 1 shows the Sources of water pollution.

Table-1: Common point and Non-Point sources of water pollution

\begin{tabular}{|c|c|}
\hline Point source & $\begin{array}{ll} & \text { Waste water effluent (Municipal and industrial). } \\
\text { - } & \text { Runoff and leachate from waste disposal site. } \\
\text { - } & \text { Runoff and inflation from animal feedlots. } \\
\text { - } & \text { Runoff from mines, oil fields, unsowed industrial sites. } \\
\text { - } & \text { Storm sewer outfall from cities of population }<100000 . \\
\text { - } & \text { Overflow of combined storms and sanitary sewers. } \\
\text { - } & \text { Runoff of construction sites }>2 \text { ha. }\end{array}$ \\
\hline $\begin{array}{l}\text { Non-point } \\
\text { source }\end{array}$ & $\begin{array}{l}\text { - Runoff from agriculture (including return flow from irrigated } \\
\text { - } \text { agriculture). } \\
\text { - } \text { Runoff from pasture and range. } \\
\text { - } \quad \text { Septic tank leachate and runoff from septic system. } \\
\text { - } \text { Runoff from construction sites <2 ha. } \\
\text { - Run off from abandoned mines } \\
\text { - Atmospheric deposition over a water surface } \\
\text { - } \text { Activities of land that generate contaminates such as logging, } \\
\text { wetland conversion, construction and development of land and } \\
\text { water ways. }\end{array}$ \\
\hline
\end{tabular}




\section{Sources of Water Pollution}

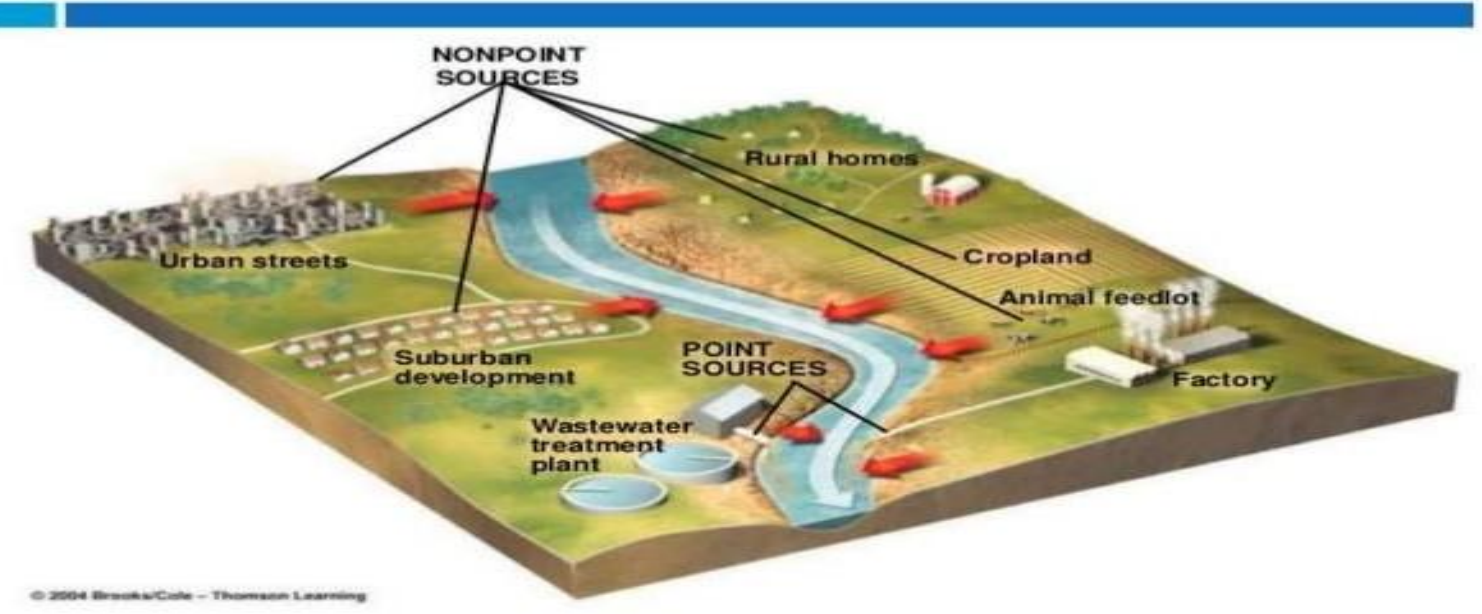

Fig. 1: Sources of water pollution [24].

In Bangladesh the main sources of water pollution are Non-point sources of pollution, though point sources have adverse effects on water pollution. Table-1 shows Common point and Non-Point sources of water pollution of Bangladesh.

\subsection{Non-Point Sources}

\subsubsection{Urban Land Use \& Heavy Rainfall}

In our urban territories, precipitation run-off as storm water is one of the major non-point source of pollution affecting the nature of our waterways and water inlets. Storm water from road surfaces is frequently degraded with auto oil and the fasces of creatures and soil and residue run-off from development destinations and in mechanical ranges regularly contains more toxicants and chemicals. Figure 2 shows the Average monthly rainfall of Bangladesh (1901-2015) and Table-2 shows Rainfall in Bangladesh from year 2011-2015.

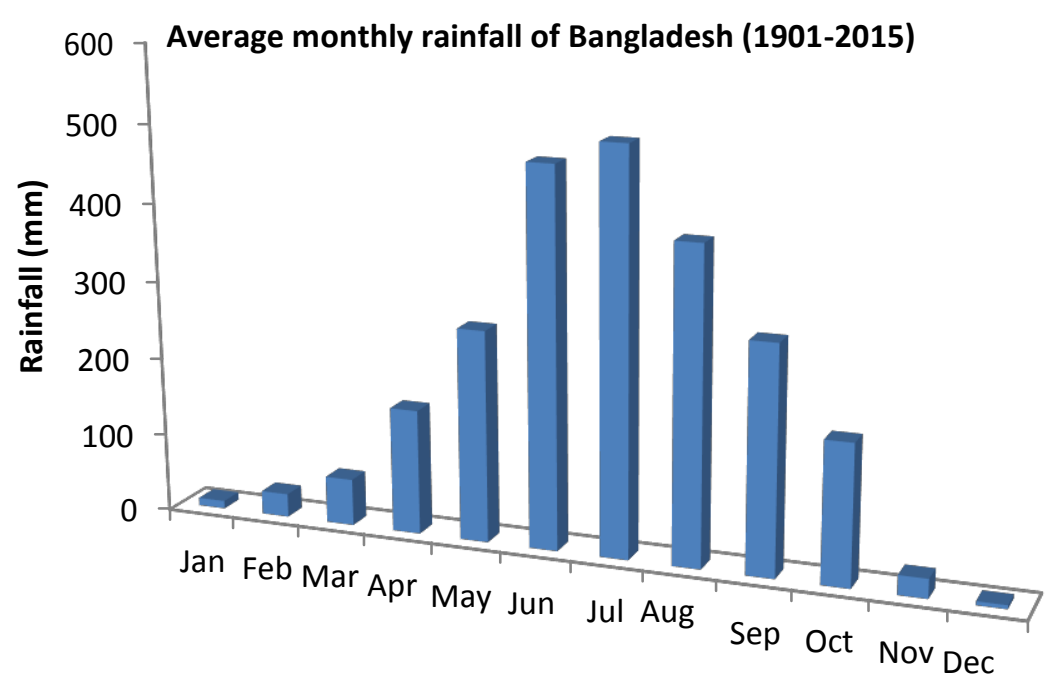

Fig. 2: Average monthly rainfall of Bangladesh (1901-2015) (Source: World Bank). 
Md. Arman Arefin and Avijjit Mallik / BIBECHANA 15 (2018) 97-112: RCOST p.101

Table-2: Rainfall in Bangladesh from year 2011-2015 [25].

\begin{tabular}{|c|c|c|}
\hline Rainfall(mm) & Year & Month \\
\hline 3.38142 & 2011 & 1 \\
\hline 17.2459 & 2011 & 2 \\
\hline 15.7637 & 2011 & 3 \\
\hline 65.5495 & 2011 & 4 \\
\hline 248.726 & 2011 & 5 \\
\hline 656.316 & 2011 & 6 \\
\hline 382.637 & 2011 & 7 \\
\hline 834.379 & 2011 & 8 \\
\hline 188.915 & 2011 & 9 \\
\hline 22.2288 & 2011 & 10 \\
\hline 7.44226 & 2011 & 11 \\
\hline 0.32617 & 2011 & 12 \\
\hline 17.4969 & 2012 & 1 \\
\hline 2.54444 & 2012 & 2 \\
\hline 29.6885 & 2012 & 3 \\
\hline 196.192 & 2012 & 4 \\
\hline 273.627 & 2012 & 5 \\
\hline 260.061 & 2012 & 6 \\
\hline 487.52 & 2012 & 7 \\
\hline 354.074 & 2012 & 8 \\
\hline 256.22 & 2012 & 9 \\
\hline 176.708 & 2012 & 10 \\
\hline 23.0077 & 2012 & 11 \\
\hline 20.4967 & 2012 & 12 \\
\hline 1.04773 & 2013 & 1 \\
\hline 11.4669 & 2013 & 2 \\
\hline 8.60079 & 2013 & 3 \\
\hline 111.975 & 2013 & 4 \\
\hline 276.491 & 2013 & 5 \\
\hline 347.167 & 2013 & 6 \\
\hline 458.96 & 2013 & 7 \\
\hline 423.581 & 2013 & 8 \\
\hline 219.738 & 2013 & 9 \\
\hline 254.105 & 2013 & 10 \\
\hline 0.73076 & 2013 & 11 \\
\hline 0.90544 & 2013 & 12 \\
\hline 0.69295 & 2014 & 1 \\
\hline 35.6462 & 2014 & 2 \\
\hline 13.9601 & 2014 & 3 \\
\hline 61.5042 & 2014 & 4 \\
\hline 173.85 & 2014 & 5 \\
\hline 333.012 & 2014 & 6 \\
\hline 385.073 & 2014 & 7 \\
\hline 474.12 & 2014 & 8 \\
\hline 335.726 & 2014 & 9 \\
\hline 57.8275 & 2014 & 10 \\
\hline 0.85865 & 2014 & 11 \\
\hline 0.53106 & 2014 & 12 \\
\hline 10.4185 & 2015 & 1 \\
\hline 22.3004 & 2015 & 2 \\
\hline 22.3094 & 2015 & 3 \\
\hline 245.063 & 2015 & 4 \\
\hline 179.614 & 2015 & 5 \\
\hline 878.927 & 2015 & 6 \\
\hline 566.637 & 2015 & 7 \\
\hline 493.387 & 2015 & 8 \\
\hline 321.713 & 2015 & 9 \\
\hline 86.5896 & 2015 & 10 \\
\hline 5.06601 & 2015 & 11 \\
\hline 5.94112 & 2015 & 12 \\
\hline
\end{tabular}


In some outer-urban and urban fringe areas, a reticulated sewerage system is not available. So sewage is discharged to onsite wastewater systems and septic tanks. Seepage and surface run-off of septic tank effluents may also be considered as non-point source of pollution of rivers in these areas.

\subsubsection{Agricultural Land Use}

In cultivating zones non-point sources of pollution incorporate pesticides, composts, creature excrement and soil washed into Rivers in precipitation run-off. Where stocks are offered access to Riverbanks they may pollute the water and quicken disintegration. Horticulture annihilates are common free frameworks. It clears characteristic vegetation and substitutes, for the common supplement and soil protection instruments, defective frameworks in which supplement misfortunes to expelled crops and by washout from bothered soils must be consistently removed by compost. It expels the supply of woody debris and jetsam, dispenses with top predators like bears and deceivers of securing household stock and may totally change the complex physical and natural structures of surge plain frameworks to advance discharge and water system. It might support the expansion of specific fish species through supplement advancement and cause significant disturbances in food products through modified predator- prey connections. It presents novel and outsider substances, for example, biocides to which there has been little time for advancement of cautious instruments. Basically despite the nearby cases of support of biodiversity by conventional farming frameworks in keeping up lakes, wet knolls and fens, agribusiness has not a positive net impact on the natural working or biodiversity of getting water. Land utilization change for farming has been notable as the real danger to oceanic biodiversity [26-29].

Farming here means change of the scene for creation of goods that are utilized for sustenance or market, regardless of whether eaten or utilized as a part of different routes by settled human social orders. It along these lines incorporates ranger service, trim culture, biomass creation for fuel and creature farming. Effects on freshwater and marine frameworks may incorporate consequences for water science [30-36] with resulting eutrophication and nourishment web adjustment [37-39], biocide filtering [40-45], suspended burdens from soil disintegration [46], change of the hydrological cycles [47], impacts of unusual species utilized, especially in fish and shellfish culture, and physical alteration of the living space (channelization, station change, bank and seepage) [48]. It is difficult to isolate impacts of horticulture from those of urbanization. Nitrogen and phosphorus filtered from fields or creature waste have very same impacts as those delivered by road seepage and human excrement.

\subsubsection{Forestry Land Use}

Forestry operations may contribute to non-point source pollution of Rivers by increasing soil erosion and sediment run-off. Figure 3 and Figure $\mathbf{4}$ show the total Forestry area and a statistical graph denoting reduction of it from 2005-2016 of Bangladesh respectively. The data of Figure 4 were collected from various government and non-governmental sources.

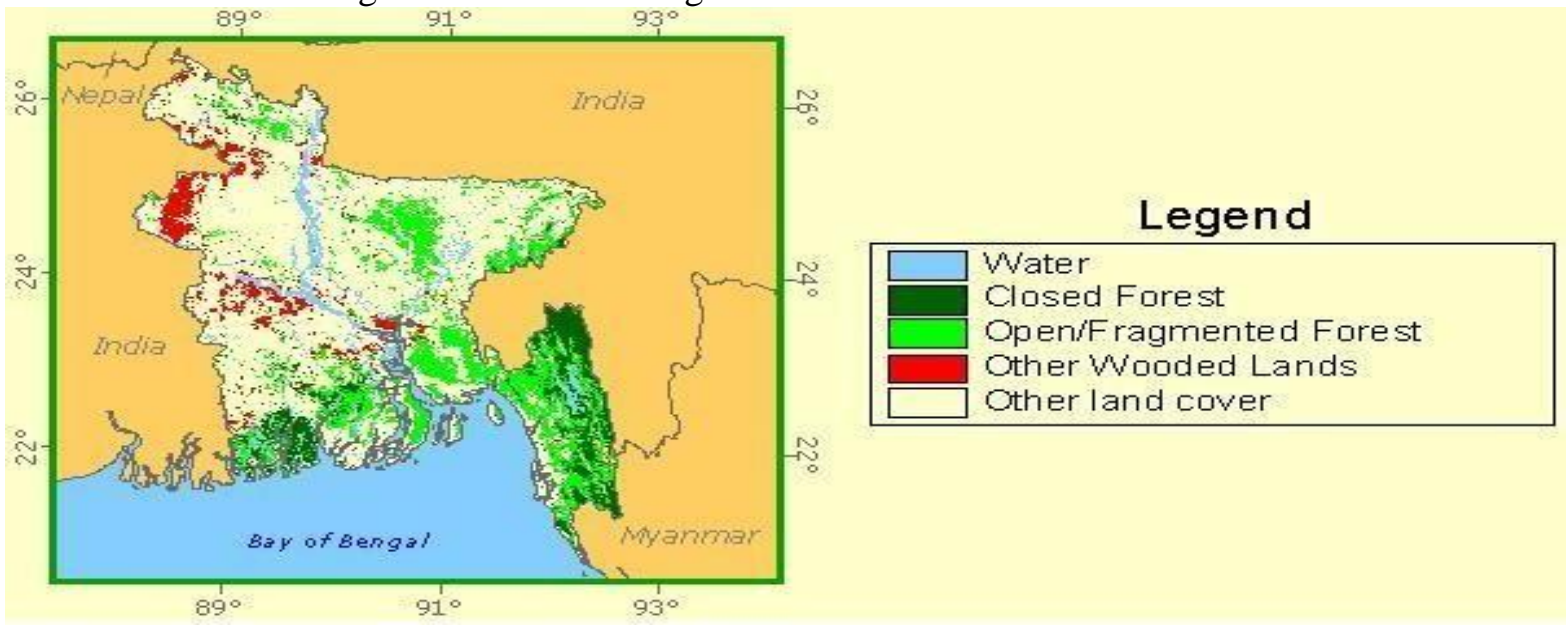

Fig. 3: Forestry lands of Bangladesh [49]. 


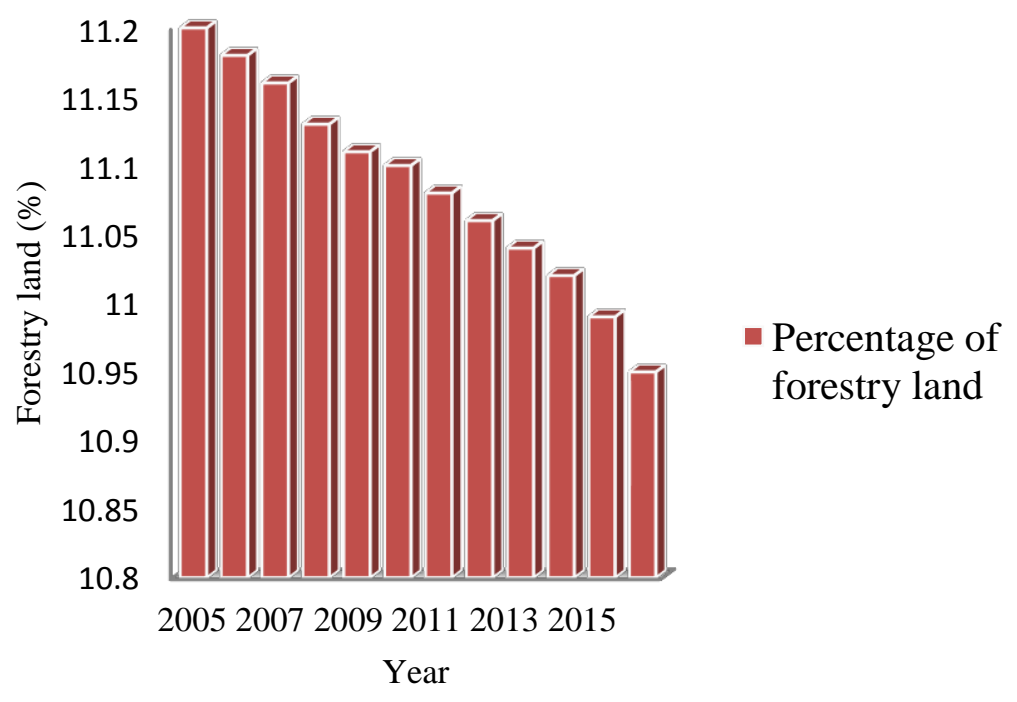

Fig. 4: Forestry land of Bangladesh (2005-2016).

\subsubsection{Abandoned Mines}

(i) Barapukuria Coal Mine:

Barapukuria coal mine is controlled by the Barapukuria Coal Mining Company Limited [50]. Barapukuria Coal Mining Company Limited is a supporting project of Petrobangla [51]. The mine is situated in Dinajpur, this is the main dynamic mine in Bangladesh [52]. Local people close to the mine have announced harms to their homes. The water close to the mine is being polluted for various point and Non-Point reasons [53]. The U.S. Geographical Survey reports that "the coal mine had a generation limit of $1 \mathrm{Mt} / \mathrm{yr}$ of coal [54].

(ii) Jamalganj Coal:

The aggregate hold of coal in the field is evaluated at 1,053 million tons. Jamalganj coal has a high unstable bituminous coal and has a normal calorific estimation of $12,100 \mathrm{btu} / \mathrm{lb}$. It is a decent quality Gondwana coal with little sulfur content. Proximate investigation demonstrates that it has 33-54\% (normal 47\%) settled carbon, 30-40\% unpredictable issue, 10-60\% (normal 22\%) fiery debris and a normal of $0.65 \%$ sulfur. The coal usually contains a variable number of non-dirt partings, fundamentally carbonaceous mudstone. Mining Jamalganj coal was deserted after the disclosure of coal in much shallower profundities in the Dinajpur-Rangpur area (Source: Banglapedia, Wikipedia, World Bank, UNESCO) [55].

(iii) Phulbari Coal mine:

The undertaking undermines has affected the homes, terrains, and water sources of upwards of 220,000 individuals. Add up to coal extraction: 572 million tons; 16 million tons every year at crest generation. (Source: Global Responsibility Venture) [56].

(iv) Khalashpir mine:

In 2003, China National Machinery Import and Export Corporation (CMC) proposed to the State Minister for Energy, A. K. M. Mosharraf Hossain to lead a specialized review of the newfound coal mine in the northern area of Rangpur district. Shan Wei, director of CMC, expressed that CMC was set up to stretch out money related and specialized help to build up the Khalashpir mine. A review was directed, in spite of the fact that it is unclear who led it. The hold would meet fuel prerequisites of the nation for no less than one hundred years; 2 million tons of coal can be separated from the coal mine each year A 400 to $500 \mathrm{MW}$ coal-based power era plant can be set up at the mine site. The mine 
site is not experiencing any type of movement, because of absence of assets. (Source: Help Information Association) [57].

\subsubsection{Hydro-Modification \& Habitat Alteration}

'Hydro-modification' alludes to alterations in normal watershed hydrology. Hydro-modification incorporates channelization and channel alteration, dams, River banks and shorelines disintegration. In Bangladesh because of channelization and direct adjustment exercises in various waterways like Buriganga, Padma, Jamuna reducing rationality of River and Riverside habitat for fish and wild life. They are additionally adjusting with river water temperature and residue sort, and in addition the rates and ways of sediment disintegration, transport and testimony. Md. Saiful Islam [55] demonstrated that the estimation of various organization of water because of Hydro-modification has changed. In his research the water tests were gathered from the Buriganga, Shitalakkhya and Turag River [58].

\subsubsection{Marinas and Boating}

Marinas and recreational boat-races are extremely famous employments of beach front waters. The development of recreational sailing, alongside the development of seaside improvement has prompted an expanded consciousness of the need to secure the ecological nature of our waterways. Since marinas are found comfortable water's edge, there is a solid potential for marina waters to wind up noticeably defiled with contaminations produced from the different activities that happen at marinas, for example, watercraft cleaning, filling operations and marine head release or from the passage of tempest water spillover from parking garages and body upkeep and repair zones into marina bowls. There are a lot of marinas and boating club in Bangladesh (Table 3) which causes water pollution tremendously.

Table 3: Marines and Boating of Bangladesh.

\begin{tabular}{ll}
\hline \multicolumn{1}{c}{ Marina \& Boating } & \multicolumn{1}{c}{ Location } \\
\hline 1. Leisure Marina Sports Village & $\begin{array}{l}\text { Serene banks of River Sitalakhya, Sripur, } \\
\text { Gazipur, Bangladesh }\end{array}$ \\
\hline 2. Chittagong Boat Club & Kaptai/Rangamati, Bangladesh \\
\hline 3. Sher-E-Bangla Club & Narsingdi, Bangladesh. \\
\hline 4. Cafe \& Boat Club & $\begin{array}{l}\text { ECB Square Zia Colony Road, Dhaka-1206, } \\
\text { Bangladesh }\end{array}$ \\
\hline 5. Dhaka Boat Club & Mirpur Road, Dhaka-1216, Bangladesh \\
\hline 6. Meghna Village Boat Club & Gazaria, Bangladesh \\
\hline 7. Kalir Bazar Boat Pier & Kalir Bazar, Bangladesh \\
\hline 8. Boat Club, Jessore & Jessore, Bangladesh \\
\hline
\end{tabular}

\subsubsection{Roads, Highways and Bridges}

Development of streets, parkways and spans result in the production of waste that can cover sea-going habitat and stop waterways. Figure 5 shows Road construction near Dhaka, Bangladesh. Substantial metals, oils, other harmful substances and debris and jetsam from development movement and spillage can be consumed by soil at development destinations and conveyed with overflow water to lakes, Rivers and bayous. 


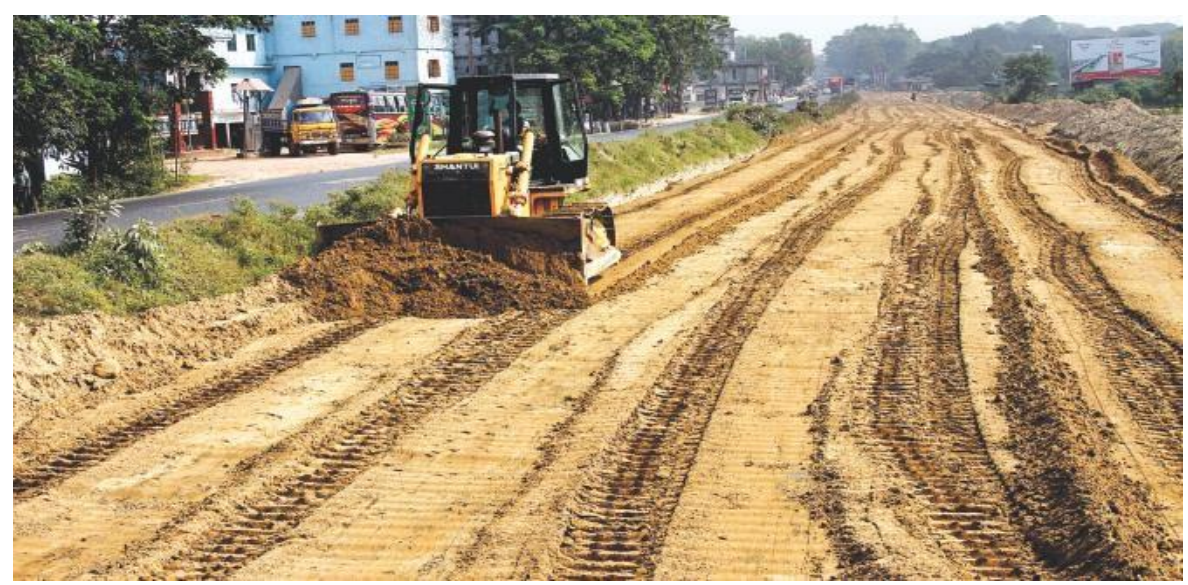

Fig. 5: Road construction near Dhaka, Bangladesh.

\subsubsection{Wetland/Riparian Areas}

Wetlands and riparian regions commonly build as characteristic cushions amongst uplands and adjoining water bodies. They go about as regular channels of nonpoint source poisons, including residue, supplements, pathogens and metals, to water bodies, for example, waterways, rivers, lakes and waterfront waters. Figure 6 shows State and management of wetlands in Bangladesh.

Wetland and riparian zones give an assortment of natural administrations that add to biological community capacities at nearby, watershed, and territorial scales [59-62] Wetlands can viably limit waste adversity, control overflow volume and decontaminate surface water [63, 64]. The shape, size, and conveyance of wetland and riparian zones are to a great extent dictated by geologic, topographic, and hydrologic conditions $[65,66]$.

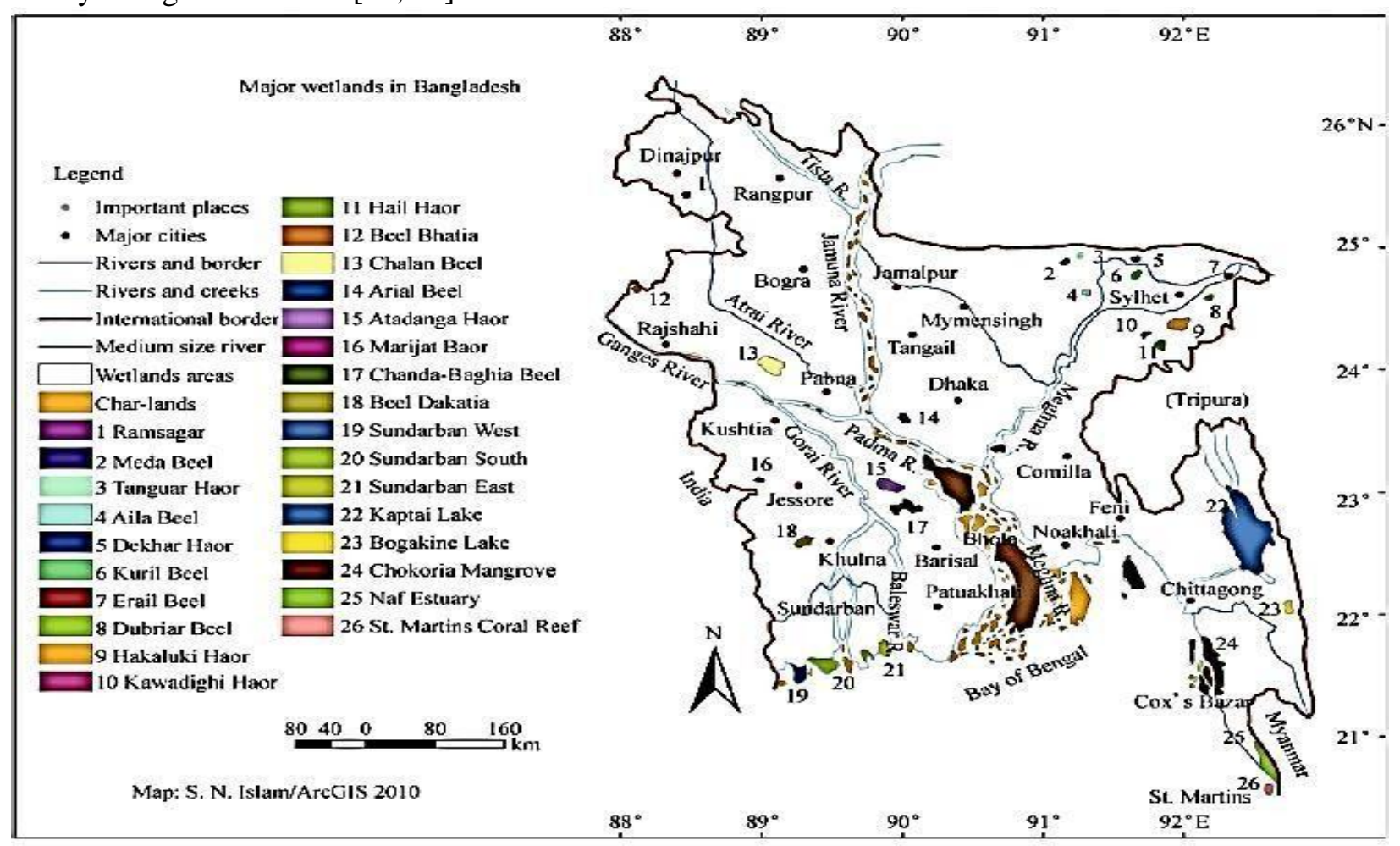

Fig. 6: State and management of wetlands in Bangladesh. (Source: AMADERPRANI). 
In Bangladesh because of absence of appropriate care and control of wetland, water pollution occurs. Study shows that the wetlands of Dhaka city are changing rapidly. In 1960, the aggregate region of water bodies and swamps were 2952.02 and 13527.58 ha, individually. While in 1988, the aggregate range of the same diminished to 2103.62 and 12717.73 ha, individually [67]. This decayed further, possessing a territory of 1990.71 ha in 2008 , which shows that the marshes kept on diminishing. Consequently the water bodies and marshes diminished by $32.57 \%$ and $52.58 \%$, separately in the middle of 1960 and 2008. These changing patterns of wetlands make the waste arrangement of Dhaka City defenseless, making water logging issues and their outcomes. Land filling and violation were perceived to be the primary explanations behind changing wetlands in the City [67].

\section{Causes of water pollution in Bangladesh}

Water pollution is caused due to several reasons. Here are the few major causes of water pollution in Bangladesh.

\subsection{Sewage and Solid Waste}

Sewage, junk and water misuse of family units, horticultural grounds and processing plants are released into lakes and Rivers. These wastes contain unsafe chemicals and poisons which make the water toxic for oceanic creatures and plants.

The unpredictable release of strong waste, local and healing facility sewage are the real causes of water pollution in Bangladesh. Around 4,000 to 4,500 tons of strong wastes are created every day and just $50 \%$ of the produced wastes are discarded in low lying ranges or into River water. These strong wastes are related with the issues of littering on streets, spilling around the containers, stopping up of channels, aimless dumping on empty plots and cause genuine natural pollution. More than 500 hospitals in Dhaka city create and discharge risky and harmful wasters without treatment [68]. The created strong misuse of six well known healing facilities/centers of Dhaka city is demonstrated as follows (Table-4).

Table 4: The generated solid waste of six famous hospitals / clinics of Dhaka city [69].

\begin{tabular}{cccccc}
\hline $\begin{array}{c}\text { Name of } \\
\text { Hospital/Clinic }\end{array}$ & $\begin{array}{c}\text { Generated } \\
\text { Waste(Kg/bed/day) }\end{array}$ & Non Hazardous Waste & \multicolumn{2}{c}{ Hazardous Waste } \\
\cline { 3 - 6 } & & $\mathbf{Q}_{\text {ty }}$ & \% of Total Waste & $\mathbf{Q}_{\text {ty }}$ & $\begin{array}{c}\text { \% of total } \\
\text { Waste }\end{array}$ \\
DMCH & 1.19 & 1.07 & 90 & 0.12 & 10 \\
SSMCH & 1.23 & 1.09 & 89 & 0.14 & 11 \\
RIHD & 1.20 & .91 & 76 & 0.29 & 24 \\
HFRCH & 1.59 & 1.29 & 81 & 0.30 & 19 \\
DNMCH & .80 & .70 & 88 & 0.10 & 12 \\
SAHL & .83 & .72 & 87 & 0.11 & 13 \\
\hline
\end{tabular}

\subsection{Industrial Waste and Effluent}

The principle mechanical activity regions of Bangladesh are at Dhaka, Chittagong, Khulna and Bogra. The main industries that cause water pollution are paper, pharmaceuticals, metal industries, sustenance industry, manure, pesticides, coloring and painting, material, tannery and so on. More than 200 Rivers of Bangladesh specifically or in a roundabout get a substantial amount of untreated mechanical wastes. Regular roughly 700 tanneries of Dhaka city are releasing around 16,000 cubic 
meters of harmful waste. The Department of Environment (DoE) has recorded 1,176 processing plants that create pollution all through the nation. Water pollution level of most five modern segments of Bangladesh in the year 2001 is shown in Figure 7.

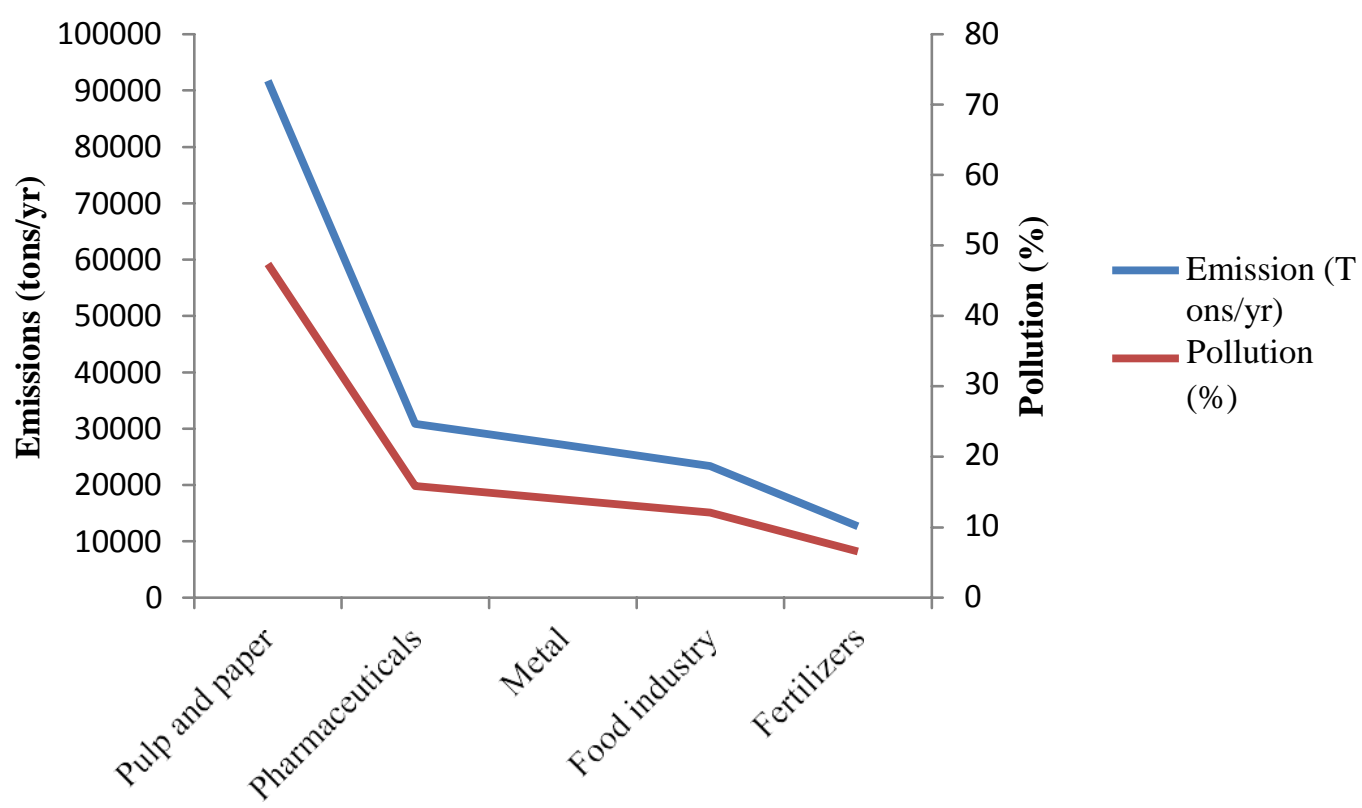

Fig. 7: Industrial emission and percentage pollution of Bangladesh (2001).

\subsection{Inadequate Sanitary Facilities}

Lacking sanitation represent a genuine natural risk of water pollution in Bangladesh. Dhaka Water and Sewerage Authority (DWASA) can serve just for 15 to $20 \%$ of city population. Without the sanitation and infrastructural administrations, $40 \%$ having septic tank and douse pit, $15 \%$ utilizing pit latrines and $30 \%$ utilizing open toilets. The sewage is for the most part discharged into low-lying territories and the untreated water causing incredible natural risks [70].

\subsection{Arsenic Contamination of Ground Water}

Arsenic in ground water imposes a genuine natural threat for Bangladesh. Around ninety-seven percent (97\%) of Bangladeshi individuals have been utilizing ground water as the primary source of drinking water yet the water has been undermined by arsenic sullying. The greater part $(52 \%)$ of the considered population drink well-water containing $>50 \mathrm{ug} / \mathrm{L}$ of arsenic and more than $66 \%(70 \%)$ drink well-water containing $>10 \mathrm{ug} / \mathrm{L}$ of arsenic. The satisfactory level of arsenic in drinking water is $0.05 \mathrm{mg} / \mathrm{L}$ for Bangladesh yet in few regions, it is discovered more than 70 times higher than that standard. Around 80 million individuals are at a danger of arsenic defilement. Table-5 shows Percentage of Ground Waters Surveyed in 1998 by the British Geological Survey Team with Arsenic Levels over the Limit. The arsenic level of ground water more than $0.05 \mathrm{mg} / \mathrm{L}$ reviewed in 1998 by the British Geological Survey group is as follows ( Table-5) [Source : World Bank, Unicef, WHO]. 
Table-5: Percentage of Ground Waters Surveyed in 1998by the British Geological Survey Team with

\begin{tabular}{cccc}
\multicolumn{4}{c}{ Arsenic Levels over the Limit [71]. } \\
\hline District & $\begin{array}{c}\text { \% of ground } \\
\text { water surveyed }\end{array}$ & District & $\begin{array}{c}\text { \% of ground } \\
\text { water surveyed }\end{array}$ \\
\hline Bagherhat & 66 & Madaripur & 93 \\
Barishal & 63 & Magura & 19 \\
Brahmanbaria & 38 & Manikganj & 15 \\
Chadpur & 96 & Meherpur & 60 \\
Chittagong & 20 & Moulovibazar & 12 \\
Chuadanga & 44 & Munshiganj & 83 \\
Comilla & 65 & Narail & 43 \\
Cox's Bazar & 3 & Narayanganj & 24 \\
Dhaka & 37 & Nowabganj & 4 \\
Faridpur & 66 & Noakhali & 75 \\
Feni & 39 & pabna & 17 \\
Gopalganj & 94 & pirojpur & 24 \\
jessore & 51 & Rajbari & 24 \\
Jhalakathi & 14 & Rajshahi & 6 \\
Jhenaidah & 26 & Satkhira & 73 \\
Khulna & 32 & Shariatpur & 80 \\
Kushtia & 28 & Sylhet & 19 \\
Lakshmipur & 68 & & \\
\hline & & &
\end{tabular}

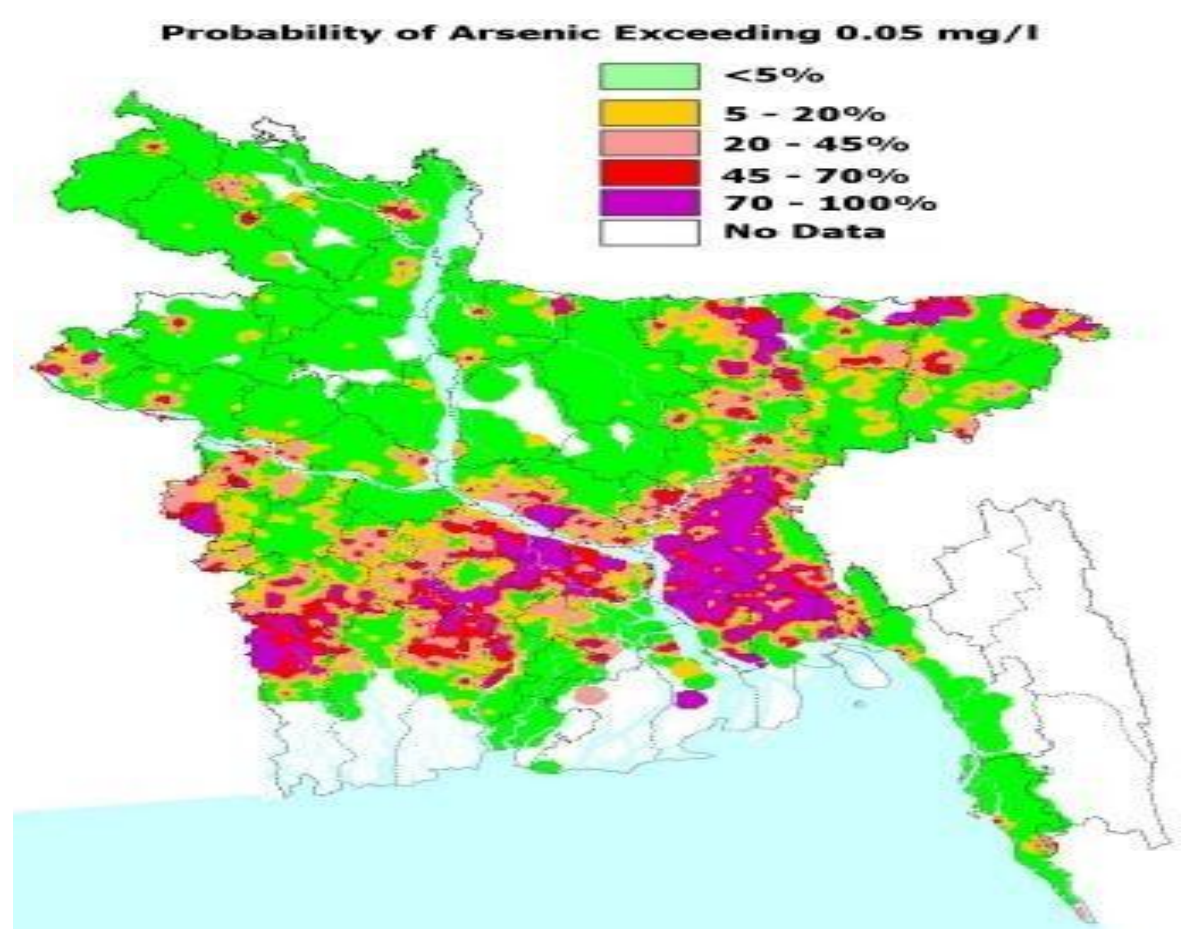

Fig. 8: Arsenic prone zone of Bangladesh.

\subsection{Oil Pollution}

River water gets contaminated because of oil spilled from boats and tankers while traveling around. The spilled oil does not break up in water and structures. In Bangladesh, mixing of oil in the river water is the main reason of river water pollution. 


\subsection{Global Warming}

In Bangladesh Due to an abrupt weather change, there is an increase in water temperature. This expansion in temperature brings about death of amphibian plants and creatures. This likewise brings about fading of coral reefs in water.

Since the worldwide normal air and sea temperatures are steadily increasing, this influences the eventual fate of Bangladesh to be at a higher danger of more disastrous events. An abrupt weather change will trigger a chain of awful occasions. At first, an abrupt weather change will cause the ocean level to rise because of warm extension and the melting of land-based ice. Notwithstanding Bangladesh being profoundly populated with a poor economy and a low-lying land, the blend of these variables will put Bangladesh in danger to an exceptionally heartbreaking circumstance later on.

\section{Conclusion}

Both surface and ground water sources in Bangladesh are exceptionally polluting and becoming very dangerous for human use as the vast majority of the poisons surpass the quality principles for drinking water. Bacteriological tainting of water is the most hazardous risk to every living being. There is an absence of appropriate observing of water quality especially in rustic zones. Bacteriological and substance pollution of public drinking water have been the reason for waterborne infections in many parts of the nation. Water sanitization education is not present is Bangladesh, though there are some agencies those give education but most of the people are not interested in all this. Legitimate care and treatment ought to be actualized to give safe water to the general population of Bangladesh.

\section{References}

[1] Sources of Water Pollution, Retrieved from: http://www.conserve-energy-future.com/sources-and-causesof-water-pollution.php (last accessed: 02/12/2017).

[2] S. R. Carpenter, N. F. Caraco, D. L. Correll, R. W. Howarth, A. N. Sharpley, V. H. Smith, Nonpoint pollution of surface waters with phosphorus and nitrogen, Eco. App. 8 (1998) 559-568. doi.org/10.1890/1051-0761(1998)008[0559:NPOSWW]2.0.CO;2.

[3] USEPA, Office of Water (4503F), U.S. Government Printing Office, Washington, D.C., USA, Retrieved from https://www.epa.gov/aboutepa/about-office-water (last accessed: 02/12/2017).

[4] S. L. Postel, Last Oasis. Second edition, Island Press, Washington, D.C., USA, 1997.

[5] S. L. Postel, G. C. Daily, P. R. Ehrlich, Human appropriation of renewable fresh water, Science. 9 (1996) 785-788. doi.org/10.1126/science.271.5250.785.

[6] B. A. Anderson, J. H. Romani, H. Phillips, M. Wentzel, K. Tlabela, Exploring environmental perceptions, behaviors and awareness: water and water pollution in South Africa, Popu. and Environ. 28 (2007) 133-61. doi.org/10.1007/s11111-007-0038-5.

[7] D. Hinrichsen, H. Tacio, The coming freshwater crisis is already here. The linkages between population and water. Washington, DC: Woodrow Wilson International Center for Scholars. (2002) 1-26. Retrieved from: https://www.wilsoncenter.org/sites/default/files/popwawa2.pdf (last accessed: 02/12/2017).

[8] Fahima Binte Amin, Water Pollution Of Most Of The Water Sources In Bangladesh, Blue \& Green, Foreign Affairs Insights and Reviews (2015). Retrieved from: http://fairbd.net/water-pollution-of-most-ofthe-water-sources-in-bangladesh (last accessed: 02/12/2017).

[9] G. Kibria, M. M. Hossain, D. Mallick, T. C. Lau, R. Wu, Monitoring of metal pollution in waterways across Bangladesh and ecological and public health implications of pollution, Chemosphere, 165 (2016) 1 9. doi.org/10.1016/j.chemosphere.2016.08.121.

[10] K. N. Mukti, Study of Sources of Pollution and its Effects on Water Quality and Human Habitat: A Case Study of Bansi River, Savar, Dhaka, Bangladesh, UITS J. 5 (2016) 33-47. Retrieved from: http://www.uits.edu.bd/research/journal/v5i1/03-Study\%20of\%20Sources\%20of\%20Pollution-33-47.pdf (last accessed: 02/12/2017).

[11] Muhammad Rezaul Kabir, Social impact assessment of water pollution: a case study on Bangshi River, Savar., PhD diss., BRAC University, 2014. 
[12] G. J. Alam, ENVIRONMENTAL POLLUTION OF BANGLADESH-IT'S EFFECT AND CONTROL, Proce. of the ICME2009, 26-28 Dec. (2009) 7-13. Retrieved from: http://me.buet.ac.bd/icme2013/icme2009/Proceedings/PDF/ICME09-RT-19.pdf (last accessed: 02/12/2017).

[13] M. A. Bhuiyan, N. I. Suruvi, S. B. Dampare, M. A. Islam, S. B. Quraishi, S. Ganyaglo, S. Suzuki, Investigation of the possible sources of heavy metal contamination in lagoon and canal water in the tannery industrial area in Dhaka, Bangladesh, Environ. Moni. Asses. 175 (2011) 633-649. doi: https://doi.org/10.1007/s10661-010-1557-6.

[14] M. Ahmad, S. Islam, M. Rahman, M. Haque, M. Islam, Heavy Metals in Water, Sediment and Some Fishes of Buriganga River, Bangladesh, Int. J. Environ. Res. 4 (2010) 321-332. doi.org/10.22059/ijer.2010.24.

[15] Nasima Tanveer Chowdhury, Water management in Bangladesh: an analytical review, Wat. Pol. 12.1 (2010) 32-51. doi.org/10.2166/wp.2009.112.

[16] M. A. Bhuiyan, M. A. Islam, S. B. Dampare, L. Parvez, S. Suzuki, Evaluation of hazardous metal pollution in irrigation and drinking water systems in the vicinity of a coal mine area of northwestern Bangladesh, J. Haz. Mat. 179(1) (2010) 1065-1077._doi.org/10.1016/j.jhazmat.2010.03.114.

[17] M. J. Hammer, Water and Wastewater Technology, John Wiley and Sons Inc., New York, USA, 1986.

[18] A. Azizullah, M. N. Khattak, P. Richter, D. P. Häder, Water pollution in Pakistan and its impact on public health—a review, J. Envint. Int. 37(2) (2011) 479-97. doi.org/10.1016/j.envint.2010.10.007.

[19] World Water Day 22.03.2010, United Nations (2010). Retrieved from: www.worldwaterday2010.info (last accessed: 02/12/2017).

[20] A. K. Biswas, Integrated water resources management: Is it working? Int. J. Wat. Res. Dev. 24(1) (2008) 5-22. doi.org/10.1080/07900620701871718.

[21] H.S. Peavy, D.R. Rowe, G. Tchobanoglous, Environmental Engineering, McGraw Hill, Inc. New York, pp. 56-70, 1985.

[22] I. A. Shiklomanov, Appraisal and assessment of world water resources, Wat. Int. 25(1) (2000) 11-32. doi.org/10.1080/02508060008686794.

[23] D. B. Jovanovich, M. I. Husseini and M. A. Chinnery, Elastic Dislocations in a Layered Half-Space-II the Point Source, Geophys. J. Int. 39 (1974) 219-239. doi.org/10.1111/j.1365-246X.1974.tb05452.x.

[24] Image of Bangladesh region's Water Pollution, https://image.slidesharecdn.com/environmentpollutionofbangladesh-150812155542-lva1app6891/95/environment-pollution-of-bangladesh-ppp-6-638.jpg?cb=1439395016 (last accessed: 02/12/2017).

[25] World Bank data on rainfall of Bangladesh, 2011-2016, Retrieved from: http://sdwebx.worldbank.org/climateportal/index.cfm?page=downscaled_data_download\& menu=historica 1 (last accessed: 02/12/2017).

[26] M. J. Vanni, K. K. Arend, M. T. Bremigan, D. B. Bunnell, J. E. Garvey, M. J. González, W. H. Renwick, P. A. Soranno, R. A. Stein, Linking landscapes and food webs: effects of omnivorous fish and watersheds on reservoir ecosystems, BioScience. 55(2) (2005) 155-67. doi.org/10.1641/00063568(2005)055[0155:LLAFWE]2.0.CO;2.

[27] P. Williams, M. Whitfield, J. Biggs, S. Bray, G. Fox, P. Nicolet, D. Sear, Comparative biodiversity of rivers, streams, ditches and ponds in an agricultural landscape in Southern England, Biol. conserv. 115(2) (2004):329-41. doi.org/10.1016/S0006-3207(03)00153-8.

[28] B. Moss, Water pollution by agriculture, Philos. Trans. R. S. L. B: Biological Sciences. 363(1491) (2008) 659-66.doi.org/10.1098/rstb.2007.2176.

[29] Jennie R. McLaren, Ariel Novoplansky, Roy Turkington, Few effects of plant functional group identity on ecosystem properties in an annual desert community, Plant eco. 217(11) (2016) 1379-1393. doi.org/10.1007/s11258-016-0660-3.

[30] P. Haygarth, Agriculture as a source of phosphorus transfer to water: sources and pathways, Scope Newsl. 21 (1997) 1-5. Retrieved from: http://moritz.botany.ut.ee/ olli/eutrsem/Ulen07.pdf (last accessed: $02 / 12 / 2017)$. 
[31] S. J. Granger, R. Bol, S. Anthony, P. N. Owens, S. M. White, P. M. Haygarth, Towards a holistic classification of diffuse agricultural water pollution from intensively managed grasslands on heavy soils, Adv. Agron. 105 (2010) 83-115. doi.org/10.1016/S0065-2113(10)05003-0.

[32] S. E. Hobbie, J. C. Finlay, B. D. Janke, D. A. Nidzgorski, D. B. Millet, L. A. Baker, Contrasting nitrogen and phosphorus budgets in urban watersheds and implications for managing urban water pollution, $\mathrm{P}$. N. A. S. 3 (2017). doi.org/10.1073/pnas.1618536114.

[33] R. T. Conant, C. E. Cerri, B. B. Osborne, K. Paustian, Grassland management impacts on soil carbon stocks: a new synthesis, Ecol. App. 27(2) (2017) 662-668. doi.org/10.1002/eap.1473.

[34] N. Cui, J. Wu, Y. Dai, Z. Li, S. Cheng, Influence of nitrogen loading and flooding on seedling emergence and recruitment from a seed bank in Chaohu Lake Basin, China, Environ. Sci. Pol. Res. 24(28) (2017) 22688-97. doi.org/10.1007/s11356-017-9926-0.

[35] J. W. Hanlon, Complementary safeguards for robust regional watershed governance in a federation: New York City and its municipal water supply. Env. Sci. 75 (2017) 47 55.doi.org/10.1016/j.envsci.2017.04.014.

[36] J. Miller, B. Beasley, C. Drury, F. Larney, X. Hao, Surface soil salinity and soluble salts after 15 applications of composted or stockpiled manure with straw or wood-chips, Compost Science \& Utilization. 25(1) (2017) 36-47. doi.org/10.1080/1065657X.2016.1176968.

[37] P. M. Glibert, Eutrophication, harmful algae and biodiversity - Challenging paradigms in a world of complex nutrient changes, J. Mar. Pol. Bul. 124(2) (2017) 591-606. doi.org/10.1016/j.marpolbul.2017.04.027.

[38] Jules N. Pretty, Christopher F. Mason, David B. Nedwell, Rachel E. Hine, Simon Leaf, Rachael Dils, Environmental costs of freshwater eutrophication in England and Wales, Environ. Sci. Technol. 37(2) (2003) 201-208. doi.org/10.1021/es020793k.

[39] D. Stephen, D. M. Balayla, E. Bécares, S. E. Collings, C. Fernández-Aláez, M. E. Fernández-Aláez, C. Ferriol, P. García, J. Gomá, M. Gyllström, L. A. Hansson, Continental-scale patterns of nutrient and fish effects on shallow lakes: introduction to a pan-European mesocosm experiment, Fresh. Bio. 49(12) (2004) 1517-24. doi.org/10.1111/j.1365-2427.2004.01302.x.

[40] T. Hanazato, Pesticide effects on freshwater zooplankton: an ecological perspective. Environ. Pol. 112(1) (2001) 1-10. doi.org/10.1016/S0269-7491(00)00110-X.

[41] E. A. Laws, Aquatic pollution: an introductory text. John Wiley \& Sons, New York, USA, 2017.

[42] P. J. Van den Brink, J. Roelsma, E. H. Van Nes, M. Scheffer, T. T. Brock, Perpest model, a case-based reasoning approach to predict ecological risks of pesticides, Environ. Tox. Chem. 21(11) (2002) 2500-6. doi.org/10.1002/etc.5620211132.

[43] A Cold, V. E. Forbes, Consequences of a short pulse of pesticide exposure for survival and reproduction of Gammarus pulex, J. Aqua. Tox. 67(3) (2004) 287-99. doi.org/10.1016/j.aquatox.2004.01.015.

[44] T. P. Traas, J. H. Janse, P. J. Van den Brink, T. Brock, T. Aldenberg, A freshwater food web model for the combined effects of nutrients and insecticide stress and subsequent recovery, J. Environ. Tox. Chem. 23(2) (2004) 521-9. doi.org/10.1897/02-524.

[45] B. T. Christensen, T. L. Lauridsen, H. W. Ravn, M. Bayley, A comparison of feeding efficiency and swimming ability of Daphnia magna exposed to cypermethrin, J. Aqua. Tox. 73(2) (2005) 210-20. doi.org/10.1016/j.aquatox.2005.03.011.

[46] J. E. Brodie, A. W. Mitchell, Nutrients in Australian tropical rivers: changes with agricultural development and implications for receiving environments, J. Mar. Freshwater Res. 56(3) (2005) 279-302. doi.org/10.1071/MF04081.

[47] W. D. Williams, N. V. Aladin, The Aral Sea: recent limnological changes and their conservation significance, Aqc. Cons. Mar. Freshwater Ecos. 1(1) (1991) 3-23. doi.org/10.1002/aqc.3270010103.

[48] P. J. Raven, N. T. Holmes, F. H. Dawson, M. Everard, Quality assessment using river habitat survey data, Aqc. Cons. Mar. Freshwater Ecos. 8(4) (1998) 477-99. doi.org/10.1002/(SICI)10990755(199807/08)8:4\%3C477::AID-AQC299\%3E3.0.CO;2-K .

[49] Philip Gain, Forest and Forest People of Bangladesh, Retrieved from : https://sites.google.com/site/bdguiber/home/6-english/bangladesh/adivasy/forest-and-forest-people-ofbangladesh (last accessed: 02/12/2017). 
[50] Mining shut in Barapukuria coal mine at Dinajpur, Dhaka Tribune (04-02-17), Retrieved from: www.dhakatribune.com/bangladesh/.../mining-shut-barapukuria-coal-mine-dinajpur (last accessed: 02/12/2017).

[51] Minerals Yearbook, 2008, V. 3, Area Reports, International, Asia and the Pacific. Government Printing Office, 2010-10-25, p. 41, ISBN 9781411329645.

[52] Barapukuria Coal Mine Workers Suspend Strike, Energy Bangla (11-01-17), Retrieved from: https://www.energybangla.com>CoalSector (last accessed: 02/12/2017).

[53] Barapukuria Coal Mine: Cracks in houses in surrounding areas, lakes drying up, Bangladesh News 24 (04-0217), Retrieved from: https://bdnews24.com/bangladesh/2016/11/26/barapukuria-coal-mine-cracks-in-houses-insurrounding-areas-lakes-drying-up(last accessed: 02/12/2017).

[54] Chin S. Kuo, The Mineral Industry of Bangladesh: 2007, U.S. Department of the Interior, U.S. Geological Survey, December, 2008.

[55] Jamalganj Coal Plant (Banglapedia), http://en.banglapedia.org/index.php?title=JamalganjCoal_(last accessed: 02/12/2017).

[56] Phulbari Coal Project Fact Sheet, https://www.culturalsurvival.org/sites/default/files/Phulbari_Coal_Project_Fact_Sheet_LowRes_(last accessed: 02/12/2017).

[57] Coal Projects on Bangladesh, http://china.aiddata.org/projects/33983?iframe=y_(last accessed: 02/12/2017).

[58] M. S. Islam, M. K. Uddin, S. M. Tareq, M. Shammi, A. K. Kamal, T Sugano, M Kurasaki, T Saito, S Tanaka, H. Kuramitz, Alteration of water pollution level with the seasonal changes in mean daily discharge in three main rivers around Dhaka City, Bangladesh, Environments. 2(3) (2015) 280-94. doi.org/10.3390/environments2030280.

[59] R. D. Semlitsch, J. R. Bodie, Are small, isolated wetlands expendable? Conserv. bio. 12(5) (1998) 1129-33. doi.org/10.1046/j.1523-1739.1998.98166.x.

[60] E. Tabacchi, D. L. Correll, R. Hauer, G. Pinay, A. M. Planty-Tabacchi, R. C. Wissmar, Development, maintenance and role of riparian vegetation in the river landscape, Freshwater Bio. 40(3) (1998) 497-516. doi.org/10.1046/j.1365-2427.1998.00381.x.

[61] J. G. Ehrenfeld, Evaluating wetlands within an urban context, Eco. Eng. 15(3) (2000) 253-65. doi.org/10.1016/S0925-8574(00)00080-X.

[62] W. J. Mitsch, J. G. Gosselink, The value of wetlands: importance of scale and landscape setting, Ecolog. Econ. 35(1) (2000) 25-33. doi.org/10.1016/S0921-8009(00)00165-8.

[63] A. Shepack, L. K. Freidenburg, D. K. Skelly, Species absence in developed landscapes: an experimental evaluation, Lands. Eco. 32(3) (2017) 609-15. doi.org/10.1007/s10980-016-0464-9.

[64] R. W. Tiner, Geographically isolated wetlands of the United States, Wetlands. 23(3) (2003) 494-516. doi.org/10.1672/0277-5212(2003)023[0494:GIWOTU]2.0.CO;2.

[65] D. E. Peck, J. R. Lovvorn, The importance of flood irrigation in water supply to wetlands in the Laramie Basin, Wyoming, USA, Wetlands. 21(3) (2001) 370-8. doi.org/10.1672/0277-5212(2001)021[0370:TIOFII]2.0.CO;2.

[66] J. Töyrä, A. Pietroniro, L. W. Martz, T. D. Prowse, A multi-sensor approach to wetland flood monitoring. Hydro. Pro. 16(8) (2002) 1569-81. doi.org/10.1002/hyp.1021.

[67] M. S. Islam, M. R. Rahman, A. K. M. Shahabuddin, R. Ahmed, Changes in wetlands in Dhaka city: trends and physico-environmental consequences, J. Life Earth Sci. 5 (2010) 37-42. doi.org/10.3329/jles.v5i0.7348.

[68] M. R. Islam, N. G. Das, P. Barua, M. B. Hossain, S. Venkatramanan, S. Y. Chung, Environmental assessment of water and soil contamination in Rajakhali Canal of Karnaphuli River (Bangladesh) impacted by anthropogenic influences: a preliminary case study, App. Wat. Sci. 7(2) (2017) 997-1010. doi.org/10.1007/s13201-015-0310-2.

[69] A. Mallik, M. A. Arefin, S. A. Ahmad, Review on Waste Management Options to Lessen Greenhouse Gas Emissions from Paper, A. J. App. Sci. Res. 3(2) (2017) 7-13. doi.org/10.11648/j.ajasr.20160302.11.

[70] I. Faisal, R. Shammin, J. Junaid, Industrial pollution in Bangladesh, The World Bank Dhaka Office, 2001. Retrieved from: https://assets.publishing.service.gov.uk/media/57a08cba40f0b652dd0014f8/R8161Diseases.pdf (last accessed: 07/12/17).

[71] A. H. Smith, E. O. Lingas, M. Rahman, Contamination of drinking-water by arsenic in Bangladesh: a public health emergency, Bul. WHO. 78(9) (2000) 1093-103. Retrieved from: http://cdrwww.who.int/entity/bulletin/archives/78(9)1093.pdf. 